\title{
The way it was and the way it should be - the new approach to the treatment of nonproliferative diabetic retinopathy
}

\author{
Marta Misiuk-Hojło ${ }^{1,2}$, Julia Kręcicka² \\ 1 Department and Clinic of Ophthalmology, Wroclaw Medical University \\ Head: Prof. Marta Misiuk-Hojło, MD, PhD \\ ${ }^{2}$ Department of Ophthalmology, University Clinical Hospital in Wroclaw \\ Head: Prof. Marta Misiuk-Hojło, MD, PhD
}

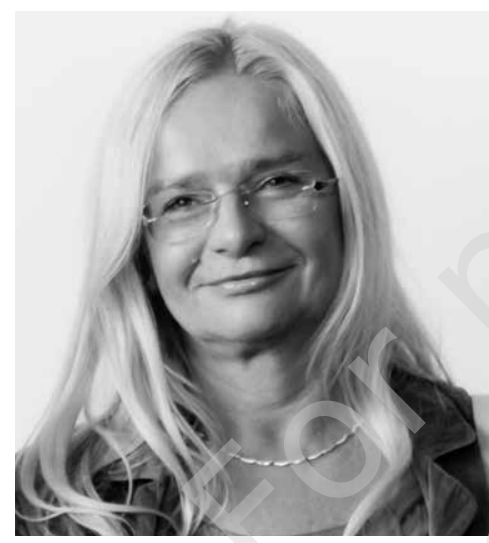

\section{ABSTRACT}

H I G H L I G H T S

Sulodexide, with its profibrinolytic, anti-inflammatory, vasoregulatory properties and protective potential toward vascular endothelium, is a promising factor in the treatment of mild and moderate diabetic retinopathy.
Diabetes has been declared an epidemic of the XXI ${ }^{\text {th }}$ century by the World Health Organisation. Diabetic retinopathy, one of its main complications, is a leading cause of vision impairment among professionally active adults. Diabetic retinopathy is a microangiopathy that affects mainly small vessels, due to their highest vulnerability to hyperglycemia. Preventive measures involve mainly strict diabetic follow-ups, balanced level of glycated hemoglobin, blood pressure values and analysis of lipids. Regular ophthalmological checkups and imaging tests of the retina are also extremely significant. For many years scientists have searched for a therapy to suppress vascular changes in diabetes. In May 2021 a stance on sulodexide use as a supporting treatment in mild and intermediate diabetic retinopathy was published by the Polish Society of Ophthalmology. Sulodexide protects vascular endothelium, contributes to endothelial cells' function and has profibrinolytic, anti-inflammatory and vasoregulatory properties. These features make it a promising protective agent in the early stages of diabetic retinopathy.

Key words: sulodexide, diabetes, diabetic retinopathy, microangiopathy, glycocalyx 
The way it was and the way it should be - the new approach to the treatment of nonproliferative diabetic retinopathy

M. Misiuk-Hojło, J. Kręcicka

\section{INTRODUCTION}

In May 2021, an Expert group position statement on the use of sulodexide as adjunctive therapy in mild to moderate diabetic retinopathy was published [1]. Already in 2014, a DRESS (Diabetic Retinopathy Sulodexide Study) was conducted to evaluate the efficacy of sulodexide among patients with non-proliferative diabetic retinopathy [2]. Although the effect of sulodexide has been proven in the early stages of diabetic retinopathy, it seems that the implementation of sulodexide treatment may contribute to patient safety and slow down the destructive progression of the disease to the retinal vessels.

\section{USING SULODEXIDE IN THE TREATMENT OF NON- -PROLIFERATIVE DIABETIC RETINOPATHY}

Sulodexide (Latin: Sulodexidum) is a compound composed of a mixture of naturally occurring glycosaminoglycans: the fast-moving heparin fraction (80\%) and dermatan sulfate (20\%). It is characterized by anticoagulant properties within arterial and venous vessels. So far, the drug has been used in the treatment of venous lower leg ulcers as an adjunct to local therapy and in the symptomatic treatment of chronic obstructive arterial disease of the lower extremities of moderate severity (grade II of the Fontaine classification). Sulodexide has been available on the Polish market since 1993 (worldwide since 1974) [3].

Sulodexide inhibits some of the clotting factors, mainly activated factor $\mathrm{X}(\mathrm{Xa})$. It also inhibits platelet adhesion and stimulates the fibrinolytic system, which further enhances its anticoagulant effect. By reducing fibrinogen levels, it normalizes blood viscosity parameters, usually altered in patients with vascular disorders and thrombotic risk. Sulodexide also contributes to normalization of blood lipid levels by activating lipoprotein lipase [4].

Contraindications include hypersensitivity to the active substance or any of the excipients, heparin or heparin-like drugs, simultaneous use of heparin or oral anticoagulants, as well as hemorrhagic diathesis or other hemorrhage-related disease. Patients should remember to regularly check blood coagulation parameters when concurrently taking other anticoagulants. Due to its molecular structure similar to heparin, sulodexide may enhance the effect of concurrently administered heparin and oral anticoagulants [4]. The drug is metabolized in the liver and mainly excreted by the kidneys. Due to insufficient data, the safety of sulodexide in children and adolescents has not yet been established.

Diabetes mellitus (DM), currently considered a global epidemic, affects both the populations of developing and highly developed countries, regardless of health care systems [5]. Diabetic retinopathy (DR) is one of the major complications of DM and is one of the leading causes of blindness among the professionally active population, affecting 2-5\% of the total population. It is more common in type 1 diabetes. Proliferative diabetic retinopathy (PDR) affects 5-10\% of diabetic patients. The most important risk factor is the duration of DM. In patients diagnosed with diabetes before 30 years of age, the incidence of diabetic retinopathy after 10 years of the disease is $50 \%$, and after 30 years as much as $90 \%$. Other risk factors include: ineffective diabetes control (increased levels of $\mathrm{HbA}_{1 \mathrm{c}}$ glycosylated hemoglobin is associated with an increased risk of PDR), pregnancy, hypertension, cardiovascular diseases, recent stroke, nephropathy, hyperlipidemia, smoking, obesity and anemia [6].

Diabetic retinopathy is a microangiopathy in which the small vessels are damaged mainly due to their greatest sensitivity to hyperglycemia. Cell damage occurs through accumulation of sorbitol, oxidative stress (associated with excess free radicals), accumulation of end products of glycation and disturbances in the functioning of ion channels. Capillary changes, manifested by leakage and occlusion of their lumen, are associated with death of the pericytes, thickening of the capillary basement membrane, loss of vascular muscle fibers, and proliferation of endothelial cells. Histological changes are accompanied by hematological pathologies (abnormalities of erythrocytes and leukocytes) and rheological pathologies (increased platelet aggregation and increased serum viscosity). The neovascularization seen in the subsequent stages of retinopathy is due to the occlusion of the small vessels, which creates devoid of perfusion areas and leads to retinal hypoxia. The disruptions between the production of angiogenic and anti-angiogenesis factors produced by retinal hypoxia have been considered to contribute to the formation of new vessels. Factors stimulating angiogenesis include vascular endothelial growth factor (VEGF), platelet growth factor and hepatocytic growth factor [6].

The earliest microscopic DR changes include thickening of the basement membrane of retinal capillaries and degeneration of pericytes.

In clinical practice, it is common to divide DR into background diabetic retinopathy (BDR), diabetic maculopathy, pre-proliferative diabetic retinopathy (PPDR), proliferative diabetic retinopathy, and advanced diabetic retinopathy. Pre-proliferative diabetic retinopathy is characterized by abnormalities such as cotton wool foci, venous changes, intraretinal microvascular abnormalities (IRMA) and retinal hemorrhages. Reaching the PPDR stage indicates progressive retinal ischemia and the risk of developing neovascularization and consequently, moving to the proliferative phase of retinopathy [6].

In the recent past, the recommended treatment for macular edema was grid and focal laser therapy. Currently, maculopathy is treated with intravitreal anti-VEGF injections or glucocorticosteroids (according to the results of The 
Diabetic Retinopathy Research Network Laser-Ranibizum-ab-Triamcinolone Study [7] multicenter study). Micropulse laser therapy plays a complementary role. The treatment of diabetic macular edema has recently been made possible by a drug program: injections of bevacizumab, aflibercept or dexamethasone in the form of an implant are used. The DME program guidelines reflect the contemporary theory of the primary role of inflammation and disruption of the blood-retinal barrier in initiating diabetic retinopathy. Panretinal photocoagulation (PRP), which effects and characteristics were described in the Diabetic Retinopathy Study (DRS) [8], remains the leading treatment for PDR. By causing regression of new vessels, PRP prevents vision loss. However, it can have a negative impact on the visual field and confers a risk of impaired central and dark vision. Intravitreal anti-VEGF injections are used as adjunctive therapy to laser treatment in PDR. Pars plana vitrectomy may be necessary when vitreoretinal traction occurs. In advanced diabetic eye disease, indications for pars plana vitrectomy include massive non-absorbing vitreous chamber hemorrhage, progressive tractional retinal detachment, mixed and tractional retinal detachment and preretinal hemorrhage (in some cases, YAG laser hyalotomy may be performed) [6].

What can one do to delay the development of proliferative retinopathy? Adequate metabolic control of diabetes, balanced values of glycated hemoglobin, blood pressure and lipidogram are of key importance. Patients should consider what other elements of the pathomechanism of early stages of retinopathy can be influenced. Besides regular check-ups with observing potential fundus lesions and periodic retinal imaging examinations, such as optical coherence tomography (OCT) and fluorescein angiography, it is worth paying attention to the quality of blood flow through its vessels.

The inner surface of blood vessels, including retinal capillary vessels, is lined with endothelial cells. Its surface is covered with a gel-like structure called the glycocalyx composed mainly of glycoproteins and proteoglycans. The glycocalyx is characterized by anticoagulant properties. Due to its negative electric charge, it provides electrostatic and mechanical protection of endothelial cells. It also determines their resistance to damage, maintains the integrity of the vascular wall and enables the communication between the flowing blood and endothelial cells $[1,9]$.

Proper endothelial status is essential for maintaining blood flow and regulating the amount of blood flow through the vessels. The endothelium is also an important component of the blood-retinal barrier [9].

Thinning of the glycocalyx layer in the vascular bed, including retinal vessels, is one of the earliest pathological processes in diabetes. Disruption of the endothelial glycocalyx contributes to increased vascular permeability [10], and endothelial cell dysfunction contributes to loss of its an- tithrombotic, profibrinolytic and vasodilatory properties. Hyperglycemia and lipid disorders increase blood viscosity, slow down its flow in retinal vessels and induce local inflammatory reaction. Together with the superimposed oxidative stress associated with hyperglycemia, this leads to diabetic damage to the retinal capillaries.

Research has been done for years to introduce a therapy to inhibit vascular changes in diabetes. Currently, the attention of scientists is attracted by the properties of sulodexide. By reducing the concentration of proinflammatory cytokines and VEGF, the compound inhibits intravascular inflammatory reaction. Moreover, it has a protective effect on the endothelium by i.a. reducing the susceptibility of cells to hyperglycemia cytotoxicity, inhibiting intracellular oxidative stress and inflammatory reaction [11-13]. With sulodexide, blood lipid levels are also reduced due to activation of lipoprotein lipase, which reduces plasma cytotoxicity to the endothelium. Sulodexide also contributes to an increase in HDL-cholesterol and a decrease in triglycerides. It is also important to highlight the profibrinolytic properties of the compound, which result in lowering fibrinogen levels, reducing blood viscosity, improving rheological properties and blood flow in small blood vessels $[4,14]$. Importantly, sulodexide includes naturally occurring glycosaminoglycans present in the glycocalyx of endothelial cells. Sulodexide modifies the structure and properties of the glycocalyx and affects the function of endothelial cells. The glycocalyx layer on the surface of retinal vascular endothelium thickens (the glycocalyx layer may become thinner under hyperglycaemia $[15,16]$ ) with a simultaneous decrease in its permeability $[10,17]$.

The efficacy of sulodexide among patients with non-proliferative diabetic retinopathy (NPDR) was evaluated in the DRESS (Diabetic Retinopathy Sulodexide Study) [2]. This randomized, controlled, multicenter clinical trial involved two 65-person groups of subjects with NPDR and hard exudates in the macular field - one group was treated with $50 \mathrm{mg}$ of sulodexide daily, the other received a placebo. The study lasted 12 months and showed a significantly greater reduction in hard exudates in the group of patients receiving sulodexide (39.0\% vs. 19.3\%). The safety profile appeared comparable in both groups. A study by Broekhuizen et al. published in "Diabetologia" journal in 2010 showed that 8-week oral sulodexide therapy leads to a statistically significant increase in retinal vascular endothelial glycocalyx layer thickness in patients with type 2 diabetes [10,3]. Another randomized, double-masked study conducted by the team of Prof. Iwona Grabska-Liberek from Warsaw, Poland, on the effectiveness of sulodexide in the treatment of hard exudates in NPDR, showed a positive effect of oral sulodexide therapy among patients at 12-month follow-up [18].

Based on the accumulated reports, the Expert Panel of the Polish Ophthalmological Society recommends the use of 
sulodexide as adjunctive therapy in the treatment of mild to moderate diabetic retinopathy. The recommended dose is one capsule (250 LSU) twice daily [1].

\section{CONCLUSIONS}

The possibility of treating previously untreatable forms of diabetic retinopathy appears to be groundbreaking. The anticoagulant, profibrinolytic, anti-inflammatory, vasoregulatory and endothelial-protective properties of sulodexide [19] are invaluable in the first phases of DR. The use of sulodexide, along with diligent monitoring of the ophthalmic status and metabolic control parameters of diabetes, including glycated hemoglobin level, lipidogram and blood pressure values, may result in slowing of changes typical of further stages of retinopathy. Involvement of the patient and interdisciplinary cooperation of doctors may result in therapeutic success. However, provision of adequate education of diabetic patients about the disease and access to diabetological and ophthalmological care still remain as major social problems in Poland.

\author{
CORRESPONDENCE \\ Julia Kręcicka, MD \\ Department of Ophthalmology, University Clinical \\ Hospital in Wroclaw \\ 50-556 Wrocław, ul. Borowska 213, budynek A, II piętro \\ e-mail: julia.krecicka@gmail.com
}

\section{ORCID}

Marta Misiuk-Hojło - ID - http://orcid.org/0000-0002-4020-3203

Julia Kręcicka - ID - http://orcid.org/0000-0003-3895-3096

\section{References}

1. Szaflik J, Misiuk-Hojło M, Romanowska-Dixon B et al. Stanowisko grupy eksperckiej w zakresie stosowania sulodeksydu jako terapii wspomagającej w łagodnej oraz średniozaawansowanej retinopatii cukrzycowej. https://pto.com.pl (access: 28.05.2021).

2. Song JH, Chin HS, Kwon OW et al; DRESS Research Group. Effect of sulodexide in patients with non-proliferative diabetic retinopathy: diabetic retinopathy sulodexide study (DRESS). Graefes Arch Clin Exp Ophthalmol. 2015; 253(6): 829-37. http://doi.org/10.1007/s00417014-2746-8. Epub 2014.

3. Misiuk-Hojło M, Jędrzejczyk R, Wodzisławska M. Farmakoterapia w leczeniu wczesnych stadiów retinopatii cukrzycowej-przypadki pacjentów. Przegląd Okulistyczny. 2020; 2(90): 8-10.

4. Charakterystyka produktu leczniczego Vessel Due F.

5. Wong TY, Sun J, Kawasaki R et al. Guidelines on Diabetic Eye Care: The International Council of Ophthalmology Recommendations for Screening, Follow-up, Referral, and Treatment Based on Resource Settings. Ophthalmology. 2018; 125(10): 1608-22. http://doi. org/10.1016/j.ophtha.2018.04.007. Epub 2018.

6. Kański JJ, Bowling B. Okulistyka kliniczna. $7^{\text {th }}$ ed., Edra Urban \& Partner / Elsevier, 2013: 531-7.

7. Bressler SB, Glassman AR, Almukhtar T et al. Diabetic Retinopathy Clinical Research Network. Five-Year Outcomes of Ranibizumab With Prompt or Deferred Laser Versus Laser or Triamcinolone Plus Deferred Ranibizumab for Diabetic Macular Edema. Am J Ophthalmol. 2016; 164: 57-68. http://doi.org/10.1016/j.ajo.2015.12.025. Epub 2016.

8. The Diabetic Retinopathy Study Research Group; Photocoagulation treatment of proliferative diabetic retinopathy: A short report of long range results., Diabetic Retinopathy Study (DRS) Report Number 4. Proceedings of the 10th Congress of the International Diabetes Federation 1979.

9. Zeng Y, Zhang XF, Fu BM et al. The Role of Endothelial Surface Glycocalyx in Mechanosensing and Transduction. Adv Exp Med Biol. 2018; 1097: 1-27. http://doi.org/10.1007/978-3-319-96445-4_1.

10. Broekhuizen LN, Lemkes BA, Mooij HL et al. Effect of sulodexide on endothelial glycocalyx and vascular permeability in patients with type 2 diabetes mellitus. Diabetologia. 2010; 53(12): 2646-55. http://doi.org/10.1007/s00125-010-1910-x. Epub 2010.

11. Połubinska A, Staniszewski R, Baum E et al. Sulodexide modifies intravascular homeostasis what affects function of the endothelium. Adv Med Sci. 2013; 58: 304-10.

12. Ciszewicz M, Polubinska A, Antoniewicz A et al. Sulodexide suppresses inflammation in human endothelial cells and prevents glucose cytotoxicity. Trans Res. 2009; 153: 118-23. 
13. Bręborowicz A. Sulodeksyd - mieszanina glikozaminoglikanów o protekcyjnym działaniu w stosunku do komórek śródbłonka naCzyniowego. Acta Angiol. 2019; 20(3): 112-8.

14. Gaddi AV, Cicero AF, Gambaro G. Nephroprotective action of glycosaminoglycans: why the pharmacological properties of sulodexide might be reconsidered. Int J Nephrol Renovasc Dis. 2010; 3: 99-105.

15. Crepaldi G, Fellin R, Calabrò A et al. Preliminary results of sulodexide treatment in patients with peripheral arteriosclerosis and hyperlipidemia. A multicentre trial. Monogr Atheroscler. 1986; 14: 215-21.

16. Ward BJ, Donnelly JL. Hypoxia induced disruption of the cardiac endothelial glycocalyx: implications for capillary permeability. Cardiovasc Res. 1993; 27: 384-9.

17. Paneni F, Beckman JA, Creager MA et al. Diabetes and vascular disease: pathophysiology, clinical consequences, and medical therapy: part I. Eur Heart J. 2013; 34(31): 2436-43. http://doi.org/10.1093/eurheartj/eht149. Epub 2013.

18. Serwatka A, Grabska-Liberek I, Tesla P. Sulodeksyd - możliwości zastosowania u pacjentów z retinopatią cukrzycową. Okulistyka. 2017; 1:74-6.

19. Carroll BJ, Piazza G, Goldhaber SZ. Sulodexide in venous disease. JThromb Haemost. 2019; 17(1):31-8. http://doi.org/10.1111/jth.14324. Epub 2018.

Authors' contributions:

Marta Misiuk-Hojto: 70\%; Julia Kręcicka: 30\%.

Conflict of interest:

None.

Financial support:

None.

Ethics:

The content presented in the article complies with the principles of the Helsinki

Declaration, EU directives and harmonized requirements for biomedical journals. 